\title{
Calving interval genetic parameters and trends for dairy breeds in South Africa
}

\author{
B.E. Mostert ${ }^{\#}$, R.R. van der Westhuizen and H.E. Theron \\ ARC-Animal Production Institute, Private Bag X2, Irene 0062, South Africa
}

\begin{abstract}
Calving interval (CI) is a fertility trait that can be used in selection programmes to minimize the negative effects that selection for production have on fertility. CI can be derived from milk recording data, therefore this fertility trait can easily be implemented in the National Dairy Genetic Evaluations of South Africa. The aim of this study was to estimate genetic parameters for CI for estimation of breeding values and genetic trends to enable South African dairy breeders to assess and select for improved fertility. Breeds included in the study were Ayrshire, Guernsey, Holstein and Jersey. Genetic parameters and trends were based on the first three CIs for all breeds. The genetic software package, VCE4, was used to estimate genetic parameters for CI. Heritabilities ranged from 0.011 for $\mathrm{CI}_{1}$ to 0.069 for $\mathrm{CI}_{2}$, both for the Guernsey breed. Genetic correlations ranged from 0.606 between $\mathrm{CI}_{2}$ and $\mathrm{CI}_{3}$ for the Guernsey breed, to 0.810 between $\mathrm{CI}_{1}$ and $\mathrm{CI}_{2}$ for the Ayrshire breed. Breeding value estimation was done using the genetic software package, PEST. The estimated breeding values were combined into an index value, using weighting factors based on the amount of information available for each trait. Genetic trends were calculated by averaging the $\mathrm{CI}_{\text {indices }}$ of measured cows per year of birth. These genetic trends indicated that CI increased genetically for all breeds. The genetic parameters will now be implemented for the estimation of CI breeding values, which can be included in selection programmes for improvement of fertility of dairy breeds in South Africa.
\end{abstract}

Keywords: Ayrshire, genetic correlations, fertility, Guernsey, heritability, Holstein, Jersey

${ }^{\#}$ Corresponding author. E-mail: Bernice@arc.agric.za

\section{Introduction}

The genetic relationship between milk production and fertility traits is antagonistic (Grosshans et al., 1997; Dematawewa \& Berger, 1998; De Jong, 1998; Jonnson et al., 1999; Castillo-Juarez et al., 2000; HaileMariam et al., 2003a; Pryce et al., 2004; VanRaden et al., 2004). Continuous selection for increased milk production therefore had and will continue to have negative effects on fertility (Haile-Mariam et al., 2003b). Deterioration in fertility traits that result from selection for milk yield can, however, be minimized or halted by considering fertility in selection programmes. Ideally a fertile cow is one that shows heat early in the mating period, conceives and maintains pregnancy (Haile-Mariam et al., 2003b). According to GonzalezRecio \& Alenda (2005), fertility traits can be classified into three groups: The first group includes traits indicating the time that a cow needs to get ready to be inseminated, e.g. Days to First Service and Heat Strength. The second group includes traits that indicate pregnancy rate, e.g. Number of Inseminations per Service, Pregnancy within 56 or 90 days, as well as Interval between First and Last Inseminations. The last group includes traits that are composite measures of time to first insemination and pregnancy rate, such as Calving Interval (CI), Days Open and Pregnancy Rate. The last group of traits can be estimated from milk recording data. The other traits require insemination and pregnancy examination records, which are not routinely recorded in South Africa. As CI is genetically correlated with various measures of fertility (Pryce et al., 1997; 1999), populations that do not record AI events can reduce fertility cost in an efficient way by selection on CI alone (Gonzalez-Recio \& Alenda, 2005). The aim of this study was to estimate genetic parameters for CI for estimation of breeding values and genetic trends to enable South African dairy breeders to assess and select for improved fertility.

\section{Material and Methods}

Calving information for the first three calving intervals of Ayrshire, Guernsey, Holstein and Jersey cows, participating in the National Dairy Animal Improvement Scheme, was downloaded from the INTERGIS (Integrated Registration and Genetic Information System). Editing entailed age restrictions within parities to ensure reasonable calving ages per parity, set according to restrictions used in the South 
African National Dairy Genetic Evaluations (Mostert et al., 2006a); allowance of a minimum CI of 210 days and a maximum of 700 days, according to specifications set in IRIS, the South African National Database Management System; and discarding data of cows sold to non-members of the Scheme. Season of calving was defined as summer (April-September) versus winter (October-March), as used in the South African National Dairy Genetic Evaluations (Mostert et al., 2006a). The contemporary group was defined as herdyear-season of calving. To ensure well-linked data structures for statistical analyses and genetic parameter estimation, the datasets were selected according to the following specifications:
- $\quad$ Only cows with a recorded first CI;
- $\quad$ Both parents had to be known;
- $\quad$ Only cows that did not change herds within a lactation;
- $\quad$ Contemporary groups consisting of at least five cows;
- $\quad$ Contemporary groups representing at least two sires;

- $\quad$ Sires had to be used in at least three contemporary groups (only for Holstein and Jersey datasets).

A 33\% and 25\% random sample were then selected for the Jersey and Holstein datasets, respectively. The Guernsey dataset was small and the subset of data that gave conversion with genetic parameter estimation, was a dataset containing records having a first and third CI and a known sire. In Table 1 information on the data structures, phenotypic averages and standard deviations of the selected datasets for the four breeds are indicated.

Analyses of variance, using SAS 9.1, indicated that for the Jersey and Guernsey breeds, age at calving should be nested within herd-year as a linear regression, while for the Holstein and Ayrshire breeds age at calving should be included as linear and quadratic regressions, but not be nested:

Guernsey and Jersey breed:

$$
\text { where: }
$$

$$
\mathrm{y}_{\mathrm{ijkl}}=\mu+\mathrm{HYS}_{\mathrm{i}}+\alpha \mathrm{CA}(\mathrm{HY})_{\mathrm{k}}+\mathrm{A}_{\mathrm{j}}+\mathrm{e}_{\mathrm{ijkl}}
$$

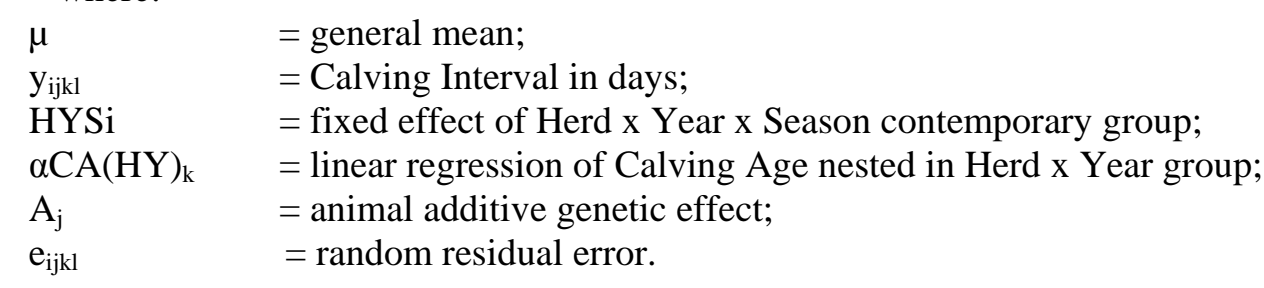

Ayrshire and Holstein breed:

where:

$$
\mathrm{y}_{\mathrm{ijkl}}=\mu+\mathrm{HYS}_{\mathrm{i}}+\alpha \mathrm{CA}+\beta C \mathrm{~A}^{2}+\mathrm{A}_{\mathrm{j}}+\mathrm{e}_{\mathrm{ijkl}}
$$

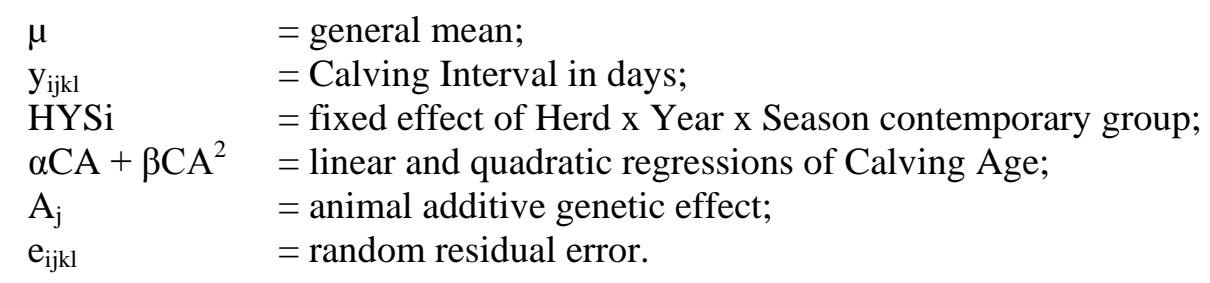

The genetic software package, VCE4 (Groeneveld \& Garcia-Cortes, 1998), was used to estimate genetic parameters for CI. The first three CIs of each breed were included as different traits in the genetic analyses and pedigrees were traced back for three generations.

Breeding value estimation was done on the unselected datasets using the genetic software package PEST (Groeneveld \& Kovac, 1990). Pedigrees were traced back as far as possible and genetic groups (based on year of birth, country of birth and selection path) for unknown parents were included to ensure that base animals enter the evaluations on the appropriate genetic level. The estimated breeding values (EBV) for the three calving intervals were combined into one index value, using weighting factors based on the relative proportion of records available for each calving interval, as follows:

$$
\mathrm{CI}_{\text {index }}=0.44 * \mathrm{EBV} \mathrm{CI}_{1}+0.33 * \mathrm{EBV} \mathrm{CI}_{2}+0.23 * \mathrm{EBV} \mathrm{CI}_{3}
$$


Genetic trends were calculated by averaging the $\mathrm{CI}_{\text {indices }}$ of measured cows per year of birth. The base of the evaluations was defined as measured cows born in 2000 (Holsteins and Jerseys) or 1995 (Ayrshires and Guernseys), as used in the South African National Dairy Genetic Evaluations (Mostert et al., 2006b).

\section{Results and Discussion}

Several countries around the world have already implemented a genetic evaluation for female fertility by 2005 (Interbull, 2005). According to Biffani et al. (2005) this is in response to the increasing concern amongst farmers, who are suffering severe reduction in income due to reproductive failure of their cows. The South African dairy industry is therefore in urgent need for fertility breeding values to improve the reproductive capacity of dairy herds in South Africa.

With regards to the data structure for CI of the different breeds, the following (Table 1): The Holstein breed, being the breed with the most recorded cows for CI in South Africa, had 39 times more measured cows compared to the Guernsey breed, which had the least number of measured cows available for breeding value estimation. Phenotypically the Ayrshire breed had the longest (404, 398 and 397 days, respectively) and the Jersey breed the shortest (389, 385 and 389 days, respectively) CIs for all three traits. Except for the Guernsey breed who had slightly more variation ( \pm 1 day) in $\mathrm{CI}_{3}$, all breeds expressed most variation for $\mathrm{CI}_{1}$. This is expected, because $\mathrm{CI}_{1}$ is represented by a more unselected part of the population compared to $\mathrm{CI}_{2}$ and $\mathrm{CI}_{3}$. With regards to the data structure, contemporary groups of the Ayrshire consisted of most cows (12.6 averaged over traits), followed by the Holstein (11.8), Jersey (9.1) and Guernsey (3.0) breeds. Average progeny per sire represented in the pedigree was most for the Holstein (30.1), followed by the Ayrshire (20.3), Jersey (19.6) and Guernsey (14.7) breeds, while average progeny per dam was rather similar for all breeds (1.8 for Guernsey, 1.7 for Ayrshire and 1.6 for Holstein and Jersey breeds).

Table 1 Information on data structures, phenotypic means and standard deviations for calving intervals 1 to 3 of the selected datasets for the different breeds

\begin{tabular}{|c|c|c|c|c|c|c|c|c|}
\hline \multirow{2}{*}{ Breed } & \multirow{2}{*}{ Trait } & \multicolumn{2}{|c|}{ No of measured cows } & \multicolumn{3}{|c|}{ No in Pedigree of } & \multirow{2}{*}{$\begin{array}{l}\text { Levels } \\
\text { in } \mathrm{CGs}^{3}\end{array}$} & \multirow{2}{*}{$\begin{array}{c}\mathrm{CI} \pm \mathrm{SD} \\
\text { (days) }\end{array}$} \\
\hline & & Before $^{1}$ & After ${ }^{2}$ & Animals & Sires & Dams & & \\
\hline \multirow[t]{3}{*}{ Ayrshire } & $\mathrm{CI}_{1}$ & 39402 & 12563 & 21227 & 1046 & 12454 & 940 & $404 \pm 70$ \\
\hline & $\mathrm{CI}_{2}$ & & 8058 & & & & 642 & $398 \pm 66$ \\
\hline & $\mathrm{CI}_{3}$ & & 4996 & & & & 428 & $397 \pm 62$ \\
\hline \multirow[t]{3}{*}{ Guernsey } & $\mathrm{CI}_{1}$ & 17965 & 3819 & 6827 & 465 & 3903 & 1238 & $393 \pm 63$ \\
\hline & $\mathrm{CI}_{2}$ & & 3797 & & & & 1255 & $390 \pm 61$ \\
\hline & $\mathrm{CI}_{3}$ & & 3819 & & & & 1288 & $396 \pm 64$ \\
\hline \multirow[t]{3}{*}{ Holstein } & $\mathrm{CI}_{1}$ & 703548 & 31546 & 87436 & 2908 & 56523 & 2080 & $398 \pm 68$ \\
\hline & $\mathrm{CI}_{2}$ & & 18962 & & & & 1689 & $394 \pm 63$ \\
\hline & $\mathrm{CI}_{3}$ & & 11869 & & & & 1316 & $395 \pm 64$ \\
\hline \multirow[t]{3}{*}{ Jersey } & $\mathrm{CI}_{1}$ & 258418 & 16394 & 45464 & 2323 & 29044 & 1512 & $389 \pm 64$ \\
\hline & $\mathrm{CI}_{2}$ & & 10915 & & & & 1273 & $385 \pm 60$ \\
\hline & $\mathrm{CI}_{3}$ & & 7294 & & & & 933 & $389 \pm 63$ \\
\hline
\end{tabular}

\footnotetext{
${ }^{1}$ Before selection, i.e. in complete dataset; ${ }^{2}$ After selection per calving interval (CI); ${ }^{3}$ Contemporary Groups.
}

In Table 2 the genetic parameters for $\mathrm{CI}_{1}-\mathrm{CI}_{3}$ are indicated for the different breeds. Heritabilities were low and ranged from $0.011 \pm 0.010$ for $\mathrm{CI}_{1}$ to $0.069 \pm 0.023$ for $\mathrm{CI}_{2}$, both for the Guernsey breed. Pryce et al . (1999), Weigel \& Rekaya (2000) and Haile-Mariam et al. (2003b) all found that fertility traits involved with the showing of oestrus after parturition to be more heritable than those involved with conceiving to service 
when inseminated. Already in the 1980s Philipsson (1982) and Hermas \& Young, (1987) concluded that although heritability for fertility is low, additive variation is considerable. This is most likely due to a high phenotypic variation and a large environmental impact on fertility traits (Ranberg, 1997).

In this study the Ayrshire, Holstein and Jersey breeds all had the highest heritability for $\mathrm{CI}_{3}: 0.061$ \pm 0.007 for Ayrshires; $0.044 \pm 0.006$ for Holsteins and $0.030 \pm 0.008$ for Jerseys, while heritabilities for $\mathrm{CI}_{1}$ and $\mathrm{CI}_{2}$ for these breeds were more comparable than the estimates for the Guernsey breed: $0.047 \pm 0.010$ and $0.044 \pm 0.008$ for Ayrshires; $0.026 \pm 0.004$ and $0.029 \pm 0.004$ for Holsteins and $0.022 \pm 0.006$ and 0.015 \pm 0.006 for Jerseys, for $\mathrm{CI}_{1}$ and $\mathrm{CI}_{2}$, respectively. These heritability estimates correspond well with those reported in the literature: Haile-Mariam et al. (2003a) and Wall et al. (2003) both reported a heritability estimate of 0.03 for CI between first and second calving of Australian and UK Holstein cows, respectively and Gonzalez-Recio \& Alenda (2005) reported an estimate of 0.04 on Spanish Holstein. Jagusiak \& Zarnecki (2006) summarized estimates for CI from the literature to range from 0.01 (Pryce et al., 2001) to 0.086 (Veerkamp et al., 2001). Makgahlela et al. (2007) reported a heritability estimate for South African Holstein cattle of 0.03 , including CIs between different lactations as repeated measures.

Some studies that included more than one CI as different traits in a genetic evaluation, showed heritability estimates to be highest for $\mathrm{CI}_{1}$ : Olori et al. (2003) published heritabilities of 0.05 for $\mathrm{CI}_{1}$ and 0.03 for each of $\mathrm{CI}_{2}$ and $\mathrm{CI}_{3}$ on the Irish Holstein population, while Jagusiak \& Zarnecki (2006) estimated heritabilities of 0.044 for $\mathrm{CI}_{1}, 0.041$ for $\mathrm{CI}_{2}$ and 0.002 for $\mathrm{CI}_{3}$ for the Polish Holstein cattle population. HaileMariam \& Kassa-Mersha (1994), however, also reported the highest heritability for $\mathrm{CI}_{3}(0.093)$, followed by $\mathrm{CI}_{1}$ (0.015), with the lowest heritability for $\mathrm{CI}_{2}$ (0.002) on Ethiopian Boran cattle.

Table 2 Genetic parameters \pm s.e. for calving intervals 1 to 3 for the different breeds (heritabilies are on the diagonal and genetic correlations on the off-diagonals)

\begin{tabular}{|c|c|c|c|c|}
\hline \multirow{2}{*}{ Breed } & \multirow{2}{*}{ Trait } & \multicolumn{3}{|c|}{ Direct ratios } \\
\hline & & $\mathrm{CI}_{1}$ & $\mathrm{CI}_{2}$ & $\mathrm{CI}_{3}$ \\
\hline \multirow{3}{*}{ Ayrshire } & $\mathrm{CI}_{1}$ & $\mathbf{0 . 0 4 7} \pm \mathbf{0 . 0 1 0}$ & $0.810 \pm 0.119$ & $0.786 \pm 0.076$ \\
\hline & $\mathrm{CI}_{2}$ & & $0.044 \pm 0.008$ & $0.770 \pm 0.102$ \\
\hline & $\mathrm{CI}_{3}$ & & & $0.061 \pm 0.007$ \\
\hline \multirow{3}{*}{ Guernsey } & $\mathrm{CI}_{1}$ & $0.069 \pm 0.023$ & $0.676 \pm 0.223$ & $0.687 \pm 0.127$ \\
\hline & $\mathrm{CI}_{2}$ & & $\mathbf{0 . 0 1 1} \pm \mathbf{0 . 0 1 0}$ & $0.606 \pm 0.200$ \\
\hline & $\mathrm{CI}_{3}$ & & & $0.037 \pm 0.013$ \\
\hline \multirow{3}{*}{ Holstein } & $\mathrm{CI}_{1}$ & $0.026 \pm 0.004$ & $0.675 \pm 0.060$ & $0.716 \pm 0.075$ \\
\hline & $\mathrm{CI}_{2}$ & & $0.029 \pm 0.004$ & $0.742 \pm 0.057$ \\
\hline & $\mathrm{CI}_{3}$ & & & $0.044 \pm 0.006$ \\
\hline \multirow{3}{*}{ Jersey } & $\mathrm{CI}_{1}$ & $0.022 \pm 0.006$ & $0.719 \pm 0.173$ & $0.725 \pm 0.118$ \\
\hline & $\mathrm{CI}_{2}$ & & $0.015 \pm 0.006$ & $0.755 \pm 0.105$ \\
\hline & $\mathrm{CI}_{3}$ & & & $0.030 \pm 0.008$ \\
\hline
\end{tabular}

Genetic correlations ranged from $0.606 \pm 0.200$ between $\mathrm{CI}_{2}$ and $\mathrm{CI}_{3}$ for the Guernsey breed, to 0.810 \pm 0.119 between $\mathrm{CI}_{1}$ and $\mathrm{CI}_{2}$ for the Ayrshire breed. The Holstein and Jersey breeds both had the highest genetic correlations between $\mathrm{CI}_{2}$ and $\mathrm{CI}_{3}(0.742 \pm 0.057$ for Holsteins and $0.755 \pm 0.105$ for Jerseys) and the 
lowest between $\mathrm{CI}_{1}$ and $\mathrm{CI}_{2}(0.675 \pm 0.060$ for Holsteins and $0.719 \pm 0.173$ for Jerseys), while the Ayrshire showed the reverse $\left(0.81 \pm 0.119\right.$ between $\mathrm{CI}_{1}$ and $\mathrm{CI}_{2}$ and $0.770 \pm 0.102$ between $\mathrm{CI}_{2}$ and $\left.\mathrm{CI}_{3}\right)$. The Guernsey breed had the highest genetic correlation between $\mathrm{CI}_{1}$ and $\mathrm{CI}_{3}(0.687 \pm 0.127)$, and the lowest between $\mathrm{CI}_{2}$ and $\mathrm{CI}_{3}(0.606 \pm 0.200)$. Genetic correlations between CIs from the literature are generally higher than the ones reported here. Haile-Mariam \& Kassa-Mersha (1994) published genetic correlations approaching unity between adjacent CIs for Boran cattle in Ethiopia: 0.999 between $\mathrm{CI}_{1}$ and $\mathrm{CI}_{2}, 0.997$ between $\mathrm{CI}_{2}$ and $\mathrm{CI}_{3}$, but a significantly lower genetic correlation of 0.653 between $\mathrm{CI}_{1}$ and $\mathrm{CI}_{3}$. HaileMariam et al. (2003a) published a correlation of 0.88 between $\mathrm{CI}_{1}$ and $\mathrm{CI}_{2}$ on Australian Holstein-Friesian cows, while Olori et al. (2003) reported the highest correlation to be between $\mathrm{CI}_{1}$ and $\mathrm{CI}_{2}(0.94)$, the lowest between $\mathrm{CI}_{1}$ and $\mathrm{CI}_{3}(0.85)$ and a correlation of 0.90 between $\mathrm{CI}_{2}$ and $\mathrm{CI}_{3}$. Genetic correlations from a study done by Makgahlela (2006) showed the same pattern as that of Olori et al. (2003): 0.82 between $\mathrm{CI}_{1}$ and $\mathrm{CI}_{2}$, 0.78 between $\mathrm{CI}_{1}$ and $\mathrm{CI}_{3}(0.85)$ and 0.99 between $\mathrm{CI}_{2}$ and $\mathrm{CI}_{3}$.

Genetic changes in CI are indicated in Figure 1 for the different breeds.

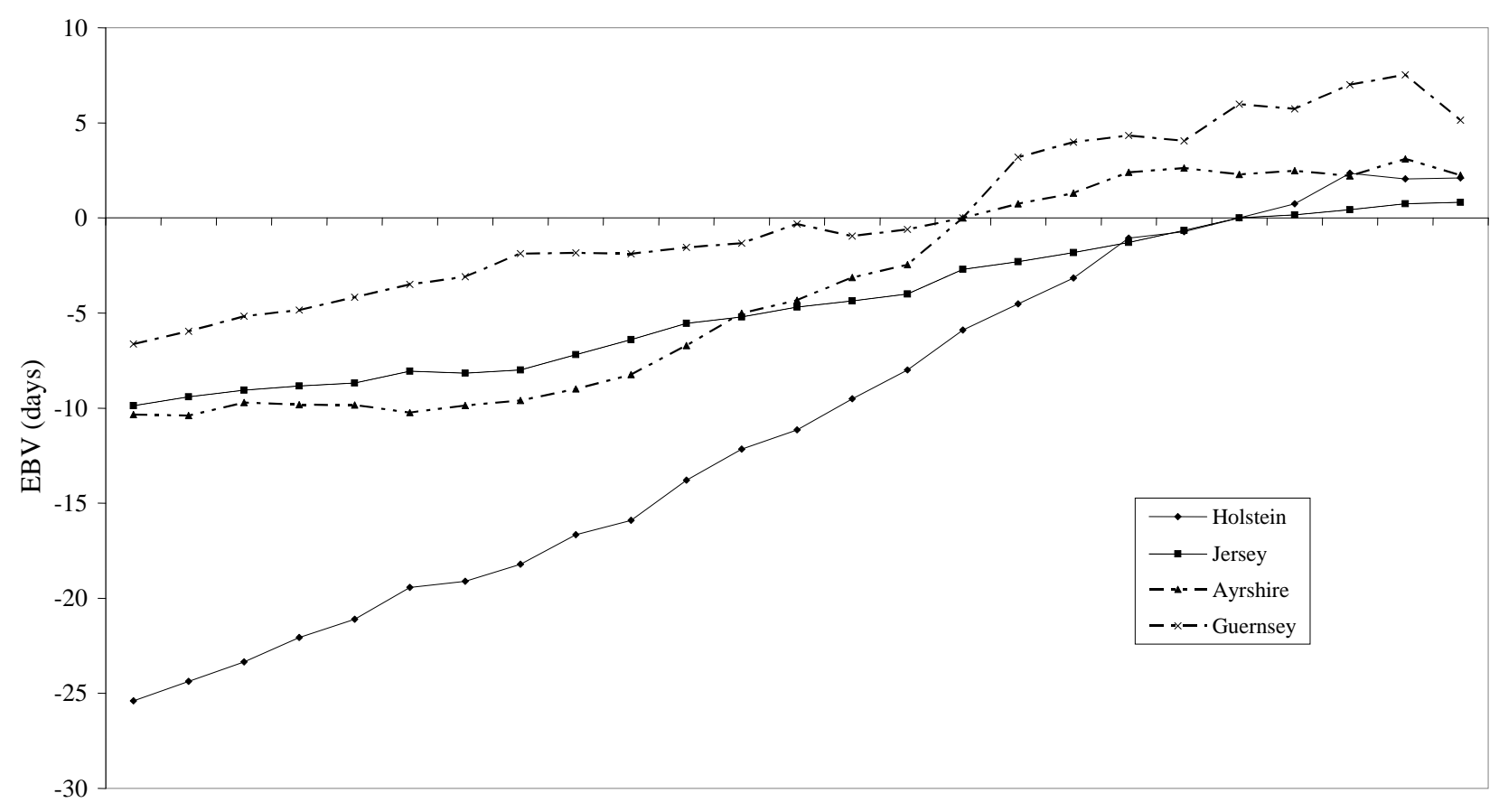

1980198119821983198419851986198719881989199019911992199319941995199619971998199920002001200220032004

Year of birth

Figure 1 Genetic trends (estimated breeding values (EBV) averaged per year of birth) for calving interval of the different dairy breeds in South Africa.

Since breeding programmes for dairy cattle in South Africa primarily focused on increased milk production for many years (Banga \& Rautenbach, 1999), it is not surprising that CI increased genetically for all breeds. The Holstein breed showed the steepest increase in CI (1.25 days/year), followed by the Ayrshire breed (0.71 days/year), Guernsey breed (0.57 days/year) and the Jersey breed showing an increase of 2.5 times less than that of the Holstein breed ( 0.50 days/year) since 1980 . This is probably due to the inclusion of Intercalving Period and Age at Calving standards in the selection of bull dams implemented by the Jersey Society since the early nineties (P. van Niekerk, Pers. Comm., Previous Breed Director: SA Jersey Society, PO Box 100893, Brandwagpark 11, Brandhof, 9324, South Africa). 


\section{Conclusions}

- Heritabilities for $\mathrm{CI}_{1-3}$ of SA dairy breeds compared well with literature estimates;

- Genetic correlations between $\mathrm{CI}_{1-3}$ of SA dairy breeds were generally lower than those reported in the literature;

- These genetic correlations clearly indicated that CIs between different parities should be treated as different traits in the SA genetic evaluations;

- CI increased genetically in all SA dairy breeds;

- CI breeding values will be released to the dairy industry as a valuable selection tool to monitor and control fertility of dairy cows and also to evaluate and improve the genetic trend of the population as a whole.

\section{References}

Banga, C.B. \& Rautenbach, L., 1999. Genetic progress from 1980 to 1999. Annual Report National Dairy Cattle Performance Testing Scheme South Africa. ARC Animal Improvement Institute, 6-11.

Biffani, S., Marusi, M., Biscarini, F. \& Canavesi, F., 2005. Developing a genetic evaluation for fertility using angularity and milk yield as correlated traits. Interbull Bulletin 33, 63-66.

Castillo-Juarez, H., Oltenacu, P.A., Blake, R.W., Mcculloch, C.E. \& Cienfuegos-Rivas, E.G., 2000. Effect of herd environment on genetic and phenotypic relationships among milk yield, conception rate and somatic cell score in Holstein cattle. J. Dairy Sci. 83, 807-814.

De Jong, G., 1998. Index for daughters' fertility in the Netherlands. Interbull Bulletin 18, 102-105.

Dematawewa, C.M.B. \& Berger, P.J., 1998. Genetic and phenotypic parameters for 305-day yield, fertility and survival in Holsteins. J. Dairy Sci. 81, 2700-2709.

Gonzalez-Recio, O. \& Alenda, R., 2005. Genetic parameters for female fertility traits and a fertility index in Spanish dairy cattle. J. Dairy Sci. 88, 3282-3289.

Groeneveld, E. \& Garcia-Cortes, A., 1998. VCE4.0, a (co)variance component package for frequentists and bayesians. Proc. $6^{\text {th }}$ World Cong. Genet. Appl. Livest. Prod. 27, 455-456.

Groeneveld, E. \& Kovac, M., 1990. A generalized computing procedure for setting up and solving mixed linear models. J. Dairy Sci. 73, 513-531.

Grosshans, T., Xu, Z.Z., Burton, L.J., Johnson, D.L. \& Macmillan, K.L., 1997. Performance and genetic parameters for fertility of seasonal dairy cows in New Zealand. Livest. Prod. Sci. 51, 41-51.

Haile-Mariam, M. \& Kassa-Mersha, 1994. Genetic and environmental effects on age at first calving and calving interval in naturally bred Boran (zebu) cows in Ethiopia. Anim. Prod. 58, 329-334.

Haile-Mariam, M., Bowman, P.J. \& Goddard, M.E., 2003a. Genetic and environmental relationship among calving interval, survival, persistency of milk yield and somatic cell count in dairy cattle. Livest. Prod. Sci. 80, 189-200.

Haile-Mariam, M., Morton, J.M. \& Goddard, M.E., 2003b. Estimates of genetic parameters for fertility traits of Australian Holstein-Friesian cattle. Anim. Sci. 76, 35-42.

Hermas, S.A. \& Young, C.W., 1987. Genetic relationships and additive genetic variation in productive and reproductive traits in Guernsey dairy cattle. J. Dairy Sci. 70, 1252-1257.

Interbull, 2005. Description of national genetic evaluation systems for dairy cattle traits as practiced in different Interbull member countries.

http://www-interbull.slu.se/national_ges_info2/framesidages.htm.

Jagusiak, W. \& Zarnecki, A., 2006. Genetic evaluation for fertility traits in Polish Holsteins. Interbull Bulletin 35, 37-41.

Jonnson, N.N., Fulkerson, W.K., Pepper, P.M. \& McGowan, M.R., 1999. Effect of genetic merit and concentrate feeding on reproduction and grazing dairy cows in a subtropical environment. J. Dairy Sci. 82, 2756-2765.

Makgahlela, M.L., 2006. Genetic analysis of female fertility traits and their relationships with yield traits in South African Holstein cattle. MSc Thesis, University of Limpopo, South Africa.

Makgahlela, M.L., Banga, C.B., Norris, D., Dzama, K. \& Ng’ambi, J.W., 2007. Genetic correlations between female fertility and production traits in South African Holstein cattle. S. Afr. J. Anim. Sci. 37, 180-188. 
Mostert, B.E., Theron, H.E., Kanfer, F.H.J. \& Van Marle-Köster, E., 2006. Fixed regression test-day models for South African dairy cattle for participation in international evaluations. S. Afr. J. Anim. Sci. 36, 58-70.

Mostert, B.E., Theron, H.E., Kanfer, F.H.J. \& Van Marle-Köster, E., 2006b. Comparison of breeding values and genetic trends for production traits estimated by a Lactation Model and a Fixed Regression Testday Model. S. Afr. J. Anim. Sci. 36, 71-78.

Olori, V.E., Pool, M.H., Calus, M.P.L., Cromie, A.R. \& Veerkamp, R.F., 2003. Joint evaluation of survival and fertility in dairy cattle with a linear model. Interbull Bulletin 30, 20-24.

Philipsson, J., 1981. Genetic aspects of female fertility in dairy cattle. Livest. Prod. Sci. 8, 307-319.

Pryce, J.E., Coffey, M.P. \& Simm, G., 2001. The relationship between body condition score and reproductive performance. J. Dairy Sci. 84, 1508-1515.

Pryce, J.E., Nielsen, B.L., Veerkamp, R.F. \& Simm, G., 1999. Genotype and feeding system effects and interactions for health and fertility traits in dairy cattle. Livest. Prod. Sci. 57, 193-201.

Pryce, J.E., Royal, M.D., Garnsworthy, P.C. \& Mao, I.L., 2004. Fertility in the high-producing dairy cow. Livest. Prod. Sci. 86, 125-135.

Pryce, J.E., Veerkamp, R.F., Thompson, R., Hill, W.G. \& Simm, G., 1997. Genetic aspects of common health disorders and measures of fertility in Holstein Friesian dairy cattle. Anim. Sci. 65, 353-360.

Ranberg, I.M.A., Steine, T. \& Klemetsdal, G., 1997. Breeding for female fertility - current status and future possibilities in Norway. Interbull Bulletin 18, 87-90.

SAS, 2009. SAS User’s Guide : Statistics, Release 9.1. SAS Institute Inc., Cary, North Carolina, USA.

VanRaden, P.M., Sanders, A.H., Tooker, M.E., Miller, R.H., Norman, H.D., Kuhn, M.T. \& Wiggans, G.R., 2004. Development of a national genetic evaluation for cow fertility. J. Dairy Sci. 87, 2285-2292.

Veerkamp, R.F., Koenen, E.P.C. \& De Jong, G., 2001. Genetic correlations among body condition score, yield and fertility in first-parity cows estimated by random regression models. J. Dairy Sci. 84, 2327-2335.

Wall, E., Brotherstone, S., Woolliams, J.A., Banos, G. \& Coffey, M.P., 2003. Genetic evaluation of fertility using direct and correlated traits. J. Dairy Sci. 86, 4093-4102.

Weigel, K.A. \& Rekaya, R., 2000. Genetic parameters for reproductive traits of Holstein cattle in California and Minnesota. J. Dairy Sci. 83, 1072-1080. 